\title{
Perceived Organisational Support As Mediator Of Distributive Justice And Job Satisfaction: The Moderating Role Of Group Commitment
}

\author{
Marc Ohana, BEM Bordeaux Management School, CREG UPPA, France
}

\begin{abstract}
We argue that distributive justice may influence employees' job satisfaction through social exchange. Based on social exchange and organizational justice theories, we develop a moderatedmediation model of the psychological processes linking distributive justice and job satisfaction and test it on a sample of 101 employees working in 27 small non-profit organizations. Results of hierarchical regressions analyses provide support for the model. We found that distributive justice was positively related to job satisfaction and also that perceived organisational support mediates this relationship. We further found that group commitment moderated the relationship between perceived organisational support and job satisfaction and that this interaction effect, in turn, mediates the distributive justice - job satisfaction relationship.
\end{abstract}

Keywords: Distributive Justice; Job Satisfaction; Perceived Organizational Support; Organizational Commitment

\section{INTRODUCTION}

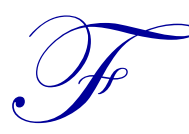

or the past 30 years, considerable research has been carried out to examine the importance of organisational justice in the workplace (Cohen-Charash \& Spector, 2001; Viswesvaran \& Ones, 2002). The three components of justice - distributive, procedural, and interactional - are the source of numerous attitudes and behaviours. Distributive justice - that most ancient component of justice, defined as the perception of equity in the allocation of resources-is an antecedent of job satisfaction, "a pleasurable or positive emotional state resulting from the appraisal of one's job or job experiences" (Locke, 1976). However, to date, the mechanism underlying that relationship has not been sufficiently examined.

In this article, we test a model of moderated mediation, the goal of which is to explain the psychological process involved in the relationship between distributive justice and job satisfaction. In order to do this, we have integrated the theories of organisational justice and social exchange (Blau, 1964). To be more specific, we propose two mechanisms by which distributive justice might have an impact on job satisfaction. First, we theorize that social exchange mediates the relation between distributive justice and job satisfaction. Second, we propose that affective commitment to the workgroup lessens the effect between social exchange and job satisfaction. Figure 1 illustrates the proposed model.

Our goal is to put forth three specific points concerning the fields of distributive justice and social exchange. In this study, we first examine the links between distributive justice and job satisfaction, without doubts the most commonly used attitude in organisational behavior. Second, to our knowledge, the mediation hypothesis of social exchange between distributive justice and job satisfaction has never been directly tested. Masterson et al. (2000) and Tekleab et al. (2005) tested it using procedural justice, but the effects of procedural vs. distributive justice may differ (Colquitt et al., 2001). Others consider only commitment or citizenship behaviours as outcomes (Loi, Hang-yue, \& Foley, 2006; Wayne, Shore, \& Bommer, 2002). Third, while some studies have shown the impact of the variables of social exchange on job satisfaction (Riggle, Edmondson, \& Hansen, 2009), rarely have studies 
integrated moderating forces. Our study thus responds to Samuel Aryee and his colleagues' call for future research to "examine the conditions (moderators) under which these variables influence their relative outcomes" (Aryee et al, 2002, p.282).

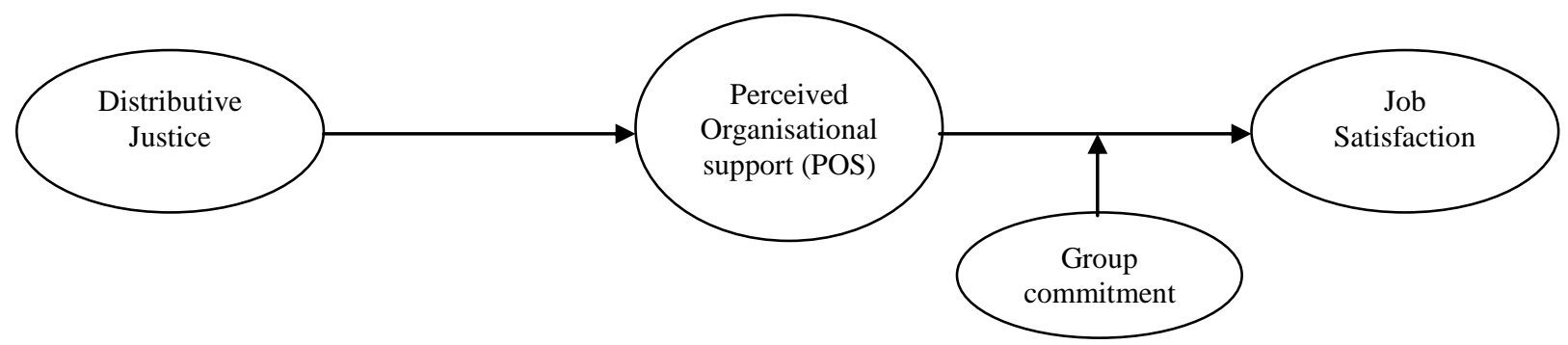

Figure 1: Hypothesized Model

The article first outlines our hypotheses. Then after explicating the methodology for data collection, we present the results, followed by the discussion of the results and a conclusion.

\section{LITERATURE REVIEW}

\section{Distributive Justice and Job Satisfaction}

Among the various types of organisational justice, distributive justice is the oldest. Distributive justice derives from the individual's perception of how resources are distributed (Greenberg, 1990). This concept of justice is based on the studies of equity theory by Adams (1963). According to this theory, individuals bring to the workplace such contributions as intensity of effort, time worked or initial training. In return, they receive benefits, such as salary and promotions. Equity theory postulates that individuals calculate the ratio of benefits to contribution. If an individual's ratio is perceived to be less than that of their colleagues, they consider themselves to be in an inequitable situation. The ideal is for individuals to perceive equity with their colleagues. Numerous research studies have shown the close links between distributive justice and attitudes and behaviours. If people feel that they are being treated fairly, they are more likely to develop positive behaviours and attitudes toward their workplace. For example, distributive justice is an antecedent of job satisfaction or a sense of well-being at work (McFarlin \& Rice, 1992; McFarlin \& Sweeney, 1992). Brief (1998) also shows that perceptions of injustice are associated with job dissatisfaction. The meta-analyses of Colquitt et al. (2001) and Cohen-Charash \& Spector (2001) demonstrate that distributive justice is tied to worker satisfaction.

This link between distributive justice and job satisfaction has three explanations (Cropanzano, Byrne, Babocel, \& Rupp, 2001). The first is instrumental (Tyler \& Blader, 2000) - fair resource allocation means that the proposed benefits to the employee are in line with his/her expectations and that they will remain so in the future. This creates satisfaction. The second explanation is relational and derives from the principle that individuals are sensitive to social relations (Lind \& Tyler, 1988) - justice satisfies the individual's need for self respect and a sense of social identity by not lowering the status of the individual in the group (Brockner \& Wiesenfeld, 1996). The last explanation is deontic (Cropanzano, Byrne, \& Bobocel, 2001) - individuals are moral beings who care about the moral or immoral character of the actions of their organization (Cropanzano, Rupp, \& Byrne, 2003). Thus, when the organisation behaves morally, the employee feels satisfaction.

Hypothesis 1: Distributive justice has a positive effect on job satisfaction.

\section{Social Exchange as A Mediator}

According to social exchange theory (Blau, 1964; Gouldner, 1960), exchanges are of two kinds - economic and social. Economic exchanges are those in which the parties attempt to extract maximum profit. The exchanges 
are impersonal and the fate of the other party is of no concern (Balkin \& Richebé, 2007; Sparrowe \& Liden, 1997). Social exchanges are of a different nature altogether. The obligations of each party are not specified a priori, either in time or character, which means that these exchanges, in contrast to economic ones, take place in the long term (Gouldner, 1960).

Social exchanges between employees and organisations are governed by the theory of organisational support (Eisenberger, Huntington, Hutchison, \& Sowa, 1986). Employees' perception of organisational support rests on their confidence in the degree to which the organisation values their contribution and is concerned with their well-being. Thus, when the organisation exemplifies distributive justice, the employee feels supported and enters into a social exchange with the organisation. This perception of support engenders, in turn, a feeling of job satisfaction. This link between the perception of organisational support and job satisfaction derives from three sources - satisfaction of socio-emotional needs, a tighter bond between performance and benefits, and knowing that assistance will be available if needed (Rhoades \& Eisenberger, 2002; Tekleab, et al., 2005).

Hypothesis 2: The perception of organisational support is a mediator of the relationship between distributive justice and job satisfaction.

\section{Group Commitment as A Moderator}

Affective commitment toward the organisation is one of the most useful attitudinal variables in organisational behaviour. It refers to the emotional link between an employee and the organization (J.P. Meyer \& Allen, 1991). While there have been many studies on organisational commitment, there are other foci of interest concerning organisations which are equally important. Commitment can be directed toward one's superiors (Becker, Billings, Eveleth, \& Gilbert, 1996) or one's team (Riketta \& Dick, 2005; Zaccaro \& Dobbins, 1989). By taking into consideration several targets of commitment, we are better able to understand the phenomenon of turnover (Stinglhamber, Bentein, \& Vandenberghe, 2002; C. Vandenberghe, Stinglhamber, Bentein, \& Delhaise, 2001), of work performance (Christian Vandenberghe, Bentein, \& Stinglhamber, 2004), and of citizenship behaviours (Bentein, Stinglhamber, \& Vandenberghe, 2002). Following from the concept of organisational commitment, commitment toward the workgroup represents, thus, an emotional attachment, identification and involvement with the team (John P. Meyer \& Herscovitch, 2001). This may be defined as the identification by the individual and his/her sense of cohesion with other members of the organisation (Cohen, 2000; Randall \& Cote, 1991).

It is known that an individual's group commitment and perception of organisational support are key to job satisfaction, but what about the interaction between the perception of organisational support and group commitment? To our knowledge, the effect of such an interaction on job satisfaction has never been researched. We can posit that the two variables have a substitutable effect. In other words, when group commitment rises, the effect of perceived organisational support (POS) from distributive justice on job satisfaction diminishes.

Indeed, the foci of POS and group commitment are different - the organisation and the workgroup. Along the same lines as the « competitive model » of Johnson et al. (Johnson, Groff, \& Taing, 2009), high levels of POS and group commitment can work against each other. It is as if group commitment functioned as a substitute for leadership (Kerr \& Jermier, 1978; Schriesheim, 1997); it is sufficient for it to be high to have job satisfaction, regardless of the level of POS deriving from distributive justice.

Hypothesis 3: The indirect effect of distributive justice on job satisfaction, via POS, should be moderated by group commitment, such that the strength of the mediated relationship is lower for high levels of group commitment than for low levels.

\section{METHOD}

\section{Sample}

Data were collected from a survey of non-profit organisations. Following an initial telephone contact, the questionnaire was mailed to directors of enterprises having more than five salaried employees under them. The 
salaried employees were asked to respond, in writing, to the questionnaire and return it in a post-paid envelope. Respondents were guaranteed anonymity.

We contacted a total of 27 enterprises, for a total of 261 employees. We received 101 responses, for a response rate of 39\%. The median age of the respondents was between 36 and 45 years and more than $92 \%$ were employed in open-ended contracts. The length of their employment with the enterprise was spread evenly among the respondents, ranging from less than two years to more than ten. About two-thirds of the respondents had a postbaccalaureate level of education. Fifty-four percent were men.

\section{Measures}

Distributive justice was measured using the five Distributive Justice Index items developed by Price and Mueller (1986). The scale ranged from 1 (very unfair) to 5 (very fair).

POS was measured by the reduced scale (3 items) of Eisenberger et al. (1986). The scale ranged from 1 (totally disagree) to 5 (totally agree).

Group Commitment was measured using three items from Allen and Meyer (1990). The scale ranged from 1 (totally disagree) to 5 (totally agree).

Job Satisfaction was measured using a three-item overall satisfaction subscale of the Michigan Organization Assessment Questionnaire (Cammann, Fichman, Jenkins, \& Klesh, 1979). The scale ranged from 1 (totally disagree) to 7 (totally agree).

\section{Analytical Strategy}

The hypotheses suggest an indirect effects model, whereby the relationship between distributive justice and satisfaction is transmitted through POS. Tests of such kind of mediation hypotheses are generally conducted using the Baron and Kenny (Baron \& Kenny, 1986) approach. However, researchers have recently questioned the appropriateness of this approach (Edwards \& Lambert, 2007; Kristopher J Preacher, Rucker, \& Hayes, 2007). They have advocated the Sobel test for assessing mediating effects, but the Sobel test assumes normality of the product terms, constituting the indirect effect which is a problematic assumption, especially in a small sample like ours (Edwards \& Lambert, 2007). We thus use bootstrap confidence intervals to derive better estimates. For the indirect effect to be meaningful, confidence intervals must exclude zero. Like other studies (e.g. Cassar \& Briner, 2011), data were thus analyzed using the strategy suggested by Preacher and Hayes (K. J. Preacher \& Hayes, 2008) in the case of mediator analyses and Preacher, Rucker, and Hayes (2007) in the case of moderated mediation.

\section{RESULTS}

Descriptive statistics, internal reliabilities and correlations are shown in Table 1.

Table 1: Descriptive Statistics, Internal Reliabilities and Correlations

\begin{tabular}{|l|c|c|c|c|c|c|c|}
\hline Variable & Mean & SD & alpha & $\mathbf{1}$ & $\mathbf{2}$ & $\mathbf{3}$ & $\mathbf{4}$ \\
\hline 1. Distributive justice & 2.83 & .99 & .93 & - & & & \\
\hline 2. POS & 3.46 & 1.02 & .82 & $.68^{* *}$ & - & & \\
\hline 3. Group commitment & 3.57 & .94 & .74 & $.40^{* *}$ & $.58^{* *}$ & - & \\
\hline 4 Job satisfaction & 5.94 & 1.15 & .83 & $.28^{* *}$ & $.52^{* *}$ & $.67^{* *}$ & - \\
\hline
\end{tabular}

$* * \mathrm{p}<.01$

Mediation analysis results for Hypotheses 1 and 2 are given in Table 2. 
Table 2: Mediator Analysis for Job Satisfaction

\begin{tabular}{|l|l|l|}
\hline & Beta & t-test \\
\hline B1 & $.33^{* *}$ & 2.89 \\
\hline B2 & $.71^{* *}$ & -18 \\
\hline B3 & -.16 & \\
\hline Sobel's Z (indirect effect) & $.49\left(\mathrm{Z}=4,57^{* *}\right)$ & \\
\hline LL 95\% percentile CI & .25 & \\
\hline UL 95\% percentile CI & .76 & \\
\hline LL 95\% bias corrected CI & .25 & \\
\hline UL 95\% bias corrected CI & .78 & \\
\hline LL 95\% bias corrected + accelerated CI & .28 & \\
\hline UL 95\% bias corrected + accelerated CI & .80 & \\
\hline
\end{tabular}

$\mathrm{B} 1=$ coefficient distributive justice on job satisfaction

$\mathrm{B} 2=$ coefficient distributive justice on POS

$\mathrm{B} 3=$ coefficient distributive on job satisfaction controlling for POS

Bootstrap resampling=5000; $\mathrm{N}=100$

$* * \mathrm{p}<.01$

First, distributive justice correlated significantly with job satisfaction $(b=0.33 ; \mathrm{p}<.01)$, supporting Hypothesis 1. However, after controlling for the mediator (POS), the coefficient fell to -.16 and is not significant. This is a case of full mediation. We confirmed the mediation effects implied in Hypotheses 2 using both the product of coefficients approach ("Sobel test") and bootstrap confidence intervals. A Sobel analysis showed that distributive justice had a significant indirect effect with job satisfaction via POS (point estimates of indirect effect=.49, $\mathrm{SE}=.11$, $\mathrm{Z}=4,57, \mathrm{p}<.01)$. We therefore calculated percentile-based, bias-corrected, and bias-corrected and accelerated confidence intervals across 5,000 bootstrap resamples. None of the confidence intervals contained zero, which further supported a significant indirect relationship between distributive justice and job satisfaction, via POS. In view of these results, Hypothesis 2 is supported.

The results of the moderated mediation analyses testing Hypothesis 3 are depicted in Table 3. Results indicated that the cross-product term between POS and group commitment on job satisfaction was significant $(\mathrm{B}=$ $.34, \mathrm{p}<.01)$.

Table 3: Moderated-Mediation Analyses of Group Commitment on the POS Mediating Pathway between Distributive Justice and Job Satisfaction

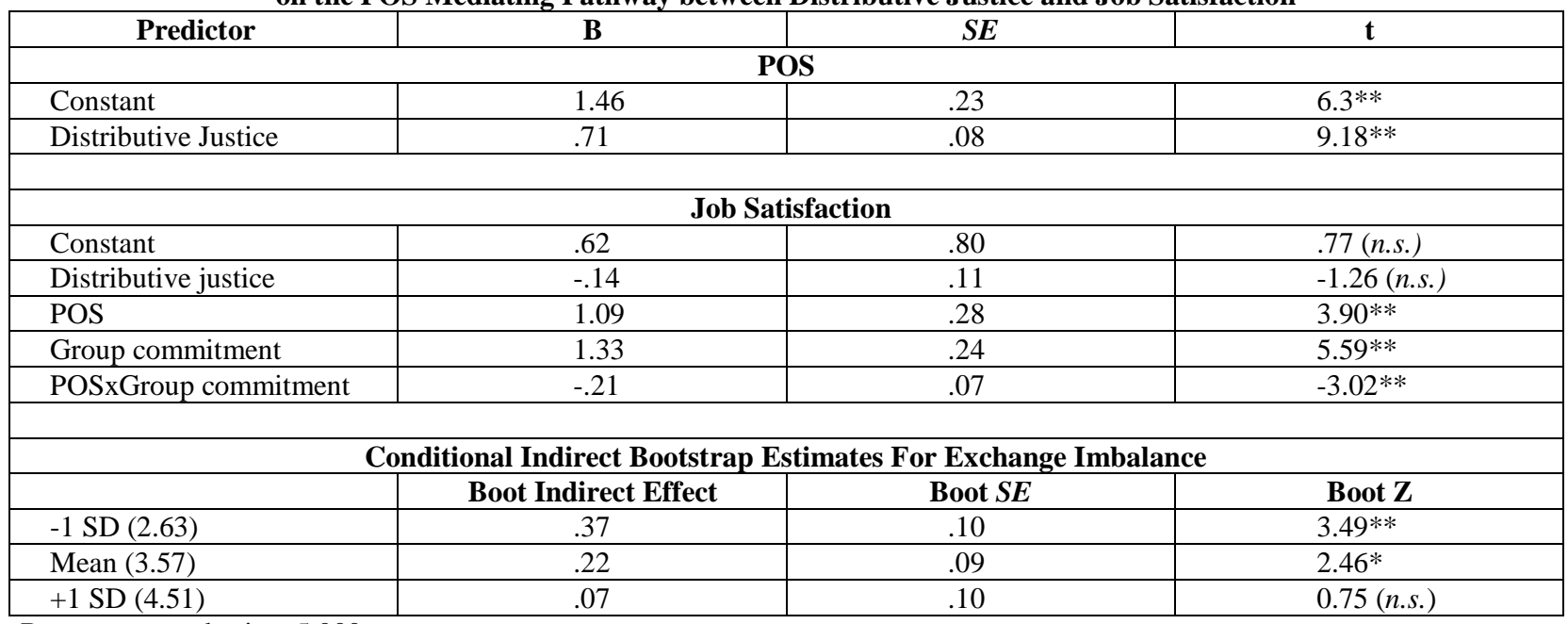

Bootstrap sample size $=5,000$

$* \mathrm{p}<.05$

$* * \mathrm{p}<.01$ 
To fully support Hypothesis 3, we needed to examine if the form of this interaction conformed to the hypothesized pattern. Therefore, we applied conventional procedures for plotting simple slopes (Figure 4) at one standard deviation above and below the mean of group commitment. Supporting Hypothesis 3, the slopes confirm the positive relationship between POS and job satisfaction for those low in group commitment and the absence of it for those highly committed to the workgroup. In other words, while distributive justice leads to POS, which in turn leads to job satisfaction, the degree of group commitment diminishes this latter relationship.

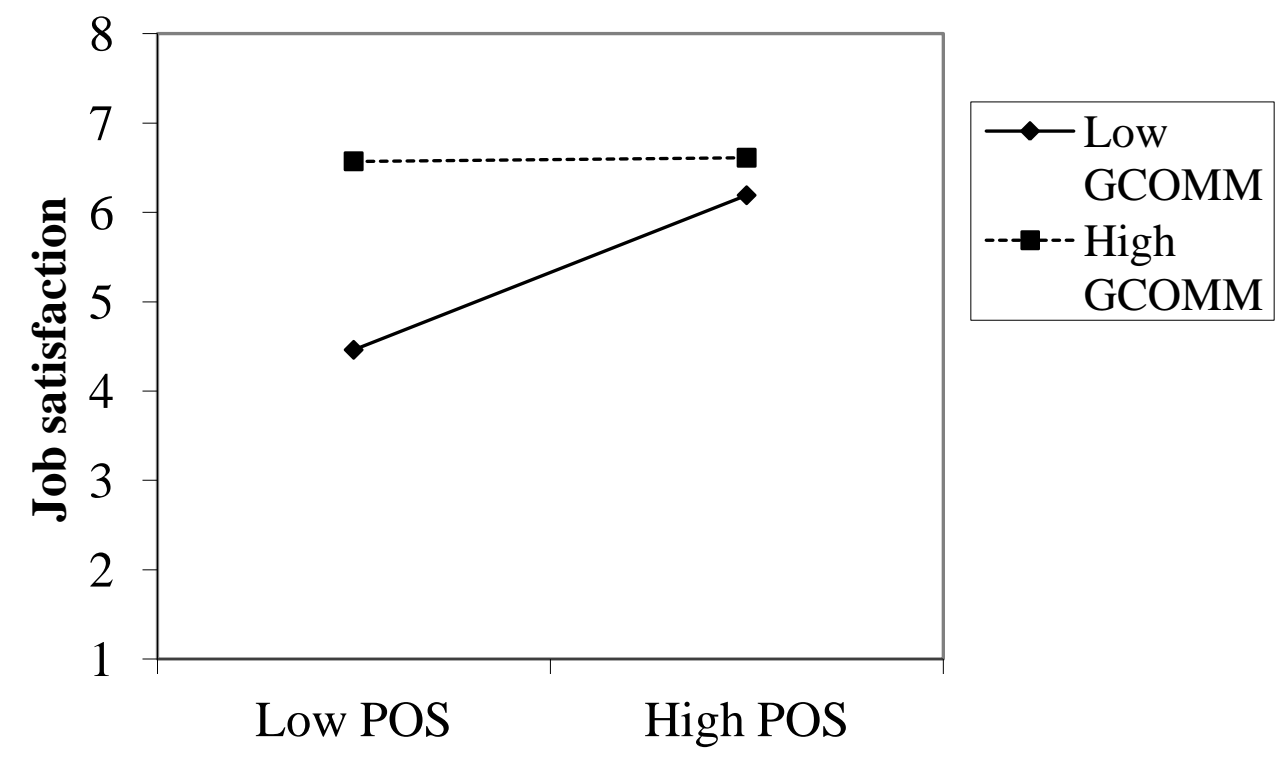

Figure 2: Job Satisfaction Predicted by POS Moderated by Group Commitment (GCOMM)

Although the results show that group commitment interacted with POS to influence job satisfaction, they do not directly assess the conditional indirect effects. Therefore, we examined the conditional indirect effect of distributive justice on job satisfaction (through POS) at three values of group commitment - the mean, one standard deviation above the mean, and one standard deviation below the mean (Table 3). Normal-theory tests indicated that two of the three conditional indirect effects (based on moderator values at the mean and at one standard deviation above the mean) were positive and significantly different from zero. Bootstrap CIs corroborated these results.

\section{DISCUSSION}

This study allows us to highlight two principal results. The first is the relationship between distributive justice and job satisfaction, mediated by POS. The second is the moderating role played by group commitment in this relationship.

First, we would like to comment on the substitutability of the variables representing the organisation (POS) and those representing the group (group commitment). While it is possible to consider variables having different foci as being complementary (Johnson, et al., 2009), our findings indicate a different result - a good workgroup climate can counterbalance the negative effects of an inequitable salary. Further research on interactions of this type between group and organisation are necessary in order to more clearly characterize the phenomenon.

Equally interesting is the role played by group commitment. Until now, studies on motivation, and more particularly studies on satisfaction, have always leaned toward explanations that are linked to the self or the organisation. Therefore, it seems important to pay closer attention to explanations concerning the group in order to better understand this phenomenon. Indeed, as emphasized by Ellemers et al. (2004), it is necessary to move from 
the self to the group in order to explain motivational attitudes and behaviour since these links have not been fully explored. Similarly, it is the role of the workgroup that should be studied more deeply than that of the organisation. This is because daily life in an organisation goes on principally in the context of the workgroup, as opposed to the abstract organisation (Moreland \& Levine, 2001; van Dick, van Knippenberg, Kerschreiter, Hertel, \& Wieseke, 2008). It is particularly important for research to explore more fully the links between distributive justice and workgroup effect since little is known about the dynamics between this concept and this level of analysis. Beyond the novelty aspect of the theory, this could have interesting implications for management, as we shall see in the next point.

Finally, this study enables us to better understand the sources of employee satisfaction. In the array of studies on work satisfaction, the link between the salary level and satisfaction is weak. In a recent overview of over 100 papers published in the four best management journals, Judge et al. (2010) finds no evidence of a strong correlation between the salary level and work satisfaction. Our study complements this well. If the absolute salary level is not a primary factor in the determination of satisfaction, our results show that the relative level is crucial. The reason is that employees perceive the fair allocation of resources to be an indicator of organisational support. The absolute level of the individual's salary should not have the same effect on the perception of organisational support since this is, without doubt, considered by employees to be an environmental constraint, a standard imposed by the market and not by the organisation.

Our study is likewise richly instructive from the management point of view. If it is relative value of remuneration, and not its absolute value which bears on satisfaction, then enterprises should be cautious with regard to their salary policies. In times of crises, salaries have a tendency to go down and many businesses are forced to lower the salaries of their employees. Although such policies are regrettable, they do not automatically have a negative effect on employee satisfaction, but human resource professionals should pay close attention to the salary distribution among employees following a pay cut. A collective cut that is perceived as fair can significantly diminish the potential negative effects on the job satisfaction of employees.

We have shown the importance of developing group commitment. This focus might be systematically neglected, to the detriment of the organisational focus, but it is critical to choose the right target to emphasize. Indeed, in the context of the current crisis, it is not always possible to strengthen loyalty to the organisation when businesses cannot guarantee employment, even for the best of their employees (John P. Meyer \& Herscovitch, 2001). Neither is it always possible to pay employees what they might expect on the market, or even at a level matching what they deserve. Thus, group commitment represents a potentially attractive substitute to fall back on.

In order to foster an affective commitment to the workgroup, a number of management strategies are possible. Determining factors include the team spirit; that is, the quality of relationships among the team members and group cohesion (Riketta \& Dick, 2005). Along these same lines, Felfe \& Yan (2009) suggest the importance of clear goals, a common vision, social support, participation in decision-making, being well informed, and good communication. Such group cohesion requires the kind of leadership which goes beyond individual self-interest and a concern for the common good. Transformational leadership is one recommended method for fostering such a group spirit (Bass, 1999).

\section{LIMITATIONS AND FUTURE RESEARCH}

This article has a number of limitations which could be avoided in future research. The first concerns the method of data collection. It is cross-sectional and derived from a single source. This risks inflating variable correlations by a common method variance bias (Podsakoff, Mackenzie, Lee, \& Podsakoff, 2003). Future studies could use a longitudinal design to correct this and obtain more reliable results.

Second, the measure of distributive justice is general and can be considered as individual distributive justice. An interesting continuation might be to distinguish between individual justice and that which is either internal or external to the organisation (Tremblay \& Roussel, 2001). This would make it possible to examine the reactions of employees to several referents, either themselves at other moments in time, one of their organisational 
colleagues, or someone in another business. Communication of the salary policy and the policy itself would thus be more precise.

\section{AUTHOR INFORMATION}

Marc Ohana is professor of organizational behavior at BEM Bordeaux Management School (France). His research mainly deals with the consequences of organizational justice on motivation by using laboratory and survey studies. E-mail: marc.ohana@ bem.edu

\section{REFERENCES}

1. Adams, J. S. (1963). Toward an understanding of inequity. Journal of Abnormal and Social Psychology, 67, 422-436.

2. Allen, N. J., \& Meyer, J. P. (1990). The measurement and antecedents of affective, continuance and normative commitment to the organization. Journal of Occupational Psychology, 63(1), 1-18.

3. Aryee, S., Budhwar, P. S., \& Chen, Z. X. (2002). Trust as a mediator of the relationship between organizational justice and work outcomes: test of a social exchange model. Journal of Organizational Behavior, 23(3), 267-285.

4. Balkin, D. B., \& Richebé, N. (2007). A gift exchange perspective on organizational training. Human Resource Management Review, 17(1), 52-62.

5. Baron, R. M., \& Kenny, D. A. (1986). The moderator-mediator variable distinction in social psychological research: Conceptual, strategic, and statistical considerations. Journal of Personality and. Social Psychology, 51, 1173-1182.

6. Bass, B. M. (1999). Two Decades of Research and Development in Transformational Leadership. European Journal of Work and Organizational Psychology, 8, 9-32.

7. Becker, T. E., Billings, R. S., Eveleth, D. M., \& Gilbert, N. L. (1996). Foci and bases of employee commitment: Implications for job performance. Academy of Management Journal, 39(2), 464-482.

8. Bentein, K., Stinglhamber, F., \& Vandenberghe, C. (2002). Organization-, supervisor-, and workgroupdirected commitments and citizenship behaviours: A comparison of models. European Journal of Work and Organizational Psychology, 11, 341-362.

9. $\quad$ Blau, P. M. (1964). Exchange and power in social life. New York: Wiley.

10. Brief, A. P. (1998). Attitudes in and around organizations. Thousand Oaks, CA Sage.

11. Brockner, J., \& Wiesenfeld, B. M. (1996). An integrative framework for explaining reactions to decisions: Interactive effects of outcomes and procedures. Psychological Bulletin, 120(2), 189-208.

12. Cammann, C., Fichman, M., Jenkins, D., \& Klesh, J. (1979). The Michigan Organizational Assessment Questionnaire.Unpublished manuscript, Ann Arbor, Michigan.

13. Cassar, V., \& Briner, R. B. (2011). The relationship between psychological contract breach and organizational commitment: Exchange imbalance as a moderator of the mediating role of violation. Journal of Vocational Behavior, 78(2), 283-289.

14. Cohen-Charash, Y., \& Spector, P. E. (2001). The Role of Justice in Organizations: A Meta-Analysis. Organizational Behavior and Human Decision Processes, 86(2), 278-321.

15. Cohen, A. (2000). The relationship between commitment forms and work outcomes: A comparison of three models. Human Relations, 53, 387.

16. Cropanzano, R., Byrne, Z. S., Babocel, R., \& Rupp, D. E. (2001). Moral Virtues, Fairness Heuristics, Social Entities, and Other Denizens of Organizational Justice. Journal of Vocational Behavior, 58, 164209.

17. Cropanzano, R., Byrne, Z. S., \& Bobocel, D. (2001). Moral Virtues, Fairness Heuristics, Social Entities, and Other Denizens of Organizational Justice. Journal of Vocational Behavior, 58, 164-209.

18. Cropanzano, R., Rupp, D. E., \& Byrne, Z. S. (2003). The relationship of emotional exhaustion to work attitudes, job performance, and organizational citizenship behaviors. Journal of Applied Psychology, 88(1), 160-169.

19. Edwards, J. R., \& Lambert, L. S. (2007). Methods for Integrating Moderation and Mediation: A General Analytical Framework Using Moderated Path Analysis. Psychological Methods, 12(1), 1-22. 
20. Eisenberger, R., Huntington, R., Hutchison, S., \& Sowa, D. (1986). Perceived organizational support. Journal of Applied Psychology, 71, 500-507.

21. Ellemers, N., de Gilder, D., \& Haslam, S. A. (2004). Motivating Individuals and Groups at Work: A Social Identity Perspective on Leadership and Group Performance. The Academy of Management Review, 29(3), 459-478.

22. Felfe, J., \& Yan, W. H. (2009). The impact of workgroup commitment on organizational citizenship behaviour, absenteeism and turnover intention: the case of Germany and China. Asia Pacific Business Review, 15, 433-450.

23. Gouldner, A. W. (1960). The Norm of Reciprocity: A Preliminary Statement. American Sociological Review, 25(1), 161-178.

24. Greenberg, J. (1990). Organizational Justice: Yesterday, Today, and Tomorrow. Journal of Management, 16(2), 399-432.

25. Johnson, R. E., Groff, K. W., \& Taing, M. U. (2009). Nature of the Interactions among Organizational Commitments: Complementary, Competitive or Synergistic? British Journal of Management, 20(4), 431447.

26. Judge, T. A., Piccolo, R. F., Podsakoff, N. P., Shaw, J. C., \& Rich, B. L. (2010). The relationship between pay and job satisfaction: A meta-analysis of the literature. Journal of Vocational Behavior, 77(2), 157-167.

27. Kerr, S., \& Jermier, J. M. (1978). Substitutes for leadership: Their meaning and measurement. Organizational Behavior and Human Performance, 22(3), 375-403.

28. Lind, E. A., \& Tyler, T. R. (1988). The social psychology of procedural justice. New York, NY, US: Plenum Press.

29. Locke, E. A. (1976). The nature and causes of job satisfaction. In M. D. Dunnette (Ed.), Handbook of Industrial and Organizational Psychology (Vol. 1, pp. 1297-1349). Chicago: Rand McNally.

30. Loi, R., Hang-Yue, N., \& Foley, S. (2006). Linking employees' justice perceptions to organizational commitment and intention to leave: The mediating role of perceived organizational support. Journal of Occupational and Organizational Psychology, 79, 101-120.

31. Masterson, S. S., Lewis, K., \& Goldman, B. M. (2000). Integrating justice and social exchange: The differing effects of fair procedures and treatment on work relationships. Academy of Management Journal, $43,738-748$.

32. McFarlin, D. B., \& Rice, R. W. (1992). The role of facet importance as a moderator in job satisfaction processes. Journal of Organizational Behavior, 13(1), 41-54.

33. McFarlin, D. B., \& Sweeney, P. D. (1992). Distributive and procedural justice as predictors of satisfaction with personal and organizational outcomes. Academy of Management Journal, 35(3), 626-637.

34. Meyer, J. P., \& Allen., N. J. (1991). A Three-Component Conceptualization of Organizational Commitment. Human Resource Management Review, 1, 61-69.

35. Meyer, J. P., \& Herscovitch, L. (2001). Commitment in the workplace: toward a general model. Human Resource Management Review, 11(3), 299-326.

36. Moreland, R. L., \& Levine, J. M. (2001). Socialization in organizations and work groups Groups at work: Theory and research (pp. 69-112). Mahwah, NJ, US: Lawrence Erlbaum Associates Publishers.

37. Podsakoff, P. M., Mackenzie, S. B., Lee, J. Y., \& Podsakoff, N. P. (2003). Common method biases in behavioral research: A critical review of the literature and recommended remedies. Journal of Applied Psychology, 88, 879-903.

38. Preacher, K. J., \& Hayes, A. F. (2008). Contemporary approaches to assessing mediation in communication research. In A. F. Hayes, M. D. Slater \& L. B. Snyder (Eds.), The Sage sourcebook of advanced data analysis methods for communication research (pp. 13-54). Thousand Oaks, CA: Sage Publications.

39. Preacher, K. J., Rucker, D. D., \& Hayes, A. F. (2007). Addressing Moderated Mediation Hypotheses: Theory, Methods, and Prescriptions. Multivariate Behavioral Research, 42, 185-227.

40. Price, J. L., \& Mueller, C. W. (1986). Handbook of organizational measurement. Marshfield, MA: Pitman.

41. Randall, D. M., \& Cote, J. A. (1991). Interrelationships of work commitment constructs. Work and occupations, 18(2), 194-211.

42. Rhoades, L., \& Eisenberger, R. (2002). Perceived organizational support: A review of the literature. Journal of Applied Psychology, 87, 698-714. 
43. Riggle, R. J., Edmondson, D. R., \& Hansen, J. D. (2009). A meta-analysis of the relationship between perceived organizational support and job outcomes: 20 years of research. Journal of Business Research, 62, 1027-1030.

44. Riketta, M., \& Dick, R. V. (2005). Foci of attachment in organizations: A meta-analytic comparison of the strength and correlates of workgroup versus organizational identification and commitment. Journal of Vocational Behavior, 67(3), 490-510.

45. Schriesheim, C. A. (1997). Substitutes-for-leadership theory: development and basic concepts. Leadership Quarterly, 8(2), 103-108.

46. Sparrowe, R. T., \& Liden, R. C. (1997). Process and Structure in Leader-Member Exchange. The Academy of Management Review, 22(2), 522-552.

47. Stinglhamber, F., Bentein, K., \& Vandenberghe, C. (2002). Extension of the Three-Component Model of Commitment to Five Foci: Development of Measures and Substantive Test. European Journal of Psychological Assessment, 18(2), 123-138.

48. Tekleab, A. G., Takeuchi, R., \& Taylor, M. S. (2005). Extending the chain of relationships among organizational justice, social exchange, and employee reactions: the role of contract violations. Academy of Management Journal, 48(1), 146-157.

49. Tremblay, M., \& Roussel, P. (2001). Modelling the role of organizational justice: effects on satisfaction and unionization propensity of Canadian. The International Journal of Human Resource Management, 12(5), 717-737.

50. Tyler, T. R., \& Blader, S. L. (2000). Cooperation in groups: Procedural justice, social identity, and behavioral engagement. New York, NY, US: Psychology Press.

51. van Dick, R., van Knippenberg, D., Kerschreiter, R., Hertel, G., \& Wieseke, J. (2008). Interactive effects of work group and organizational identification on job satisfaction and extra-role behavior. Journal of Vocational Behavior, 72(3), 388-399.

52. Vandenberghe, C., Bentein, K., \& Stinglhamber, F. (2004). Affective commitment to the organization, supervisor, and work group: Antecedents and outcomes. Journal of Vocational Behavior, 64, 47-71.

53. Vandenberghe, C., Stinglhamber, S., Bentein, K., \& Delhaise, T. (2001). An examination of the crosscultural validity of a multidimensional model of commitment in Europe. Journal of Cross-Cultural Psychology, 32(322-347).

54. Viswesvaran, C., \& Ones, D. S. (2002). Examining the Construct of Organizational Justice: A MetaAnalytic Evaluation of Relations with Work Attitudes and Behaviors. Journal of Business Ethics, 38, 193203.

55. Wayne, S. J., Shore, L. M., \& Bommer, W. H. (2002). The role of fair treatment and rewards in perceptions of organizational support and leader-member exchange. Journal of Applied Psychology, 87, 590-598.

56. Zaccaro, S. J., \& Dobbins, G. H. (1989). Contrasting group and organizational commitment: Evidence for differences among multilevel attachments. Journal of Organizational Behavior, 10(3), 267-273. 